\title{
Article \\ Comprehensive Survey of Various Energy Storage Technology Used in Hybrid Energy
}

\author{
Ahmed Riyaz ${ }^{1,2, *(\mathbb{D})}$, Pradip Kumar Sadhu ${ }^{1}$, Atif Iqbal ${ }^{3}{ }^{[}$and Basem Alamri ${ }^{4}(\mathbb{C}$ \\ 1 Electrical Engineering Department, Indian Institute of Technology (Indian School of Mines) Dhanbad, \\ Dhanbad 826004, India; pradip@iitism.ac.in \\ 2 Electrical Engineering Department, BGSB University, Rajouri 185234, India \\ 3 Electrical Engineering Department, Qatar University, Doha 2713, Qatar; atif.iqbal@qu.edu.qa \\ 4 Department of Electrical Engineering, Taif University, Taif 21944, Saudi Arabia; b.alamri@tu.edu.sa \\ * Correspondence: riyazamu@gmail.com
}

check for updates

Citation: Riyaz, A.; Sadhu, P.K.; Iqbal, A.; Alamri, B. Comprehensive Survey of Various Energy Storage Technology Used in Hybrid Energy. Electronics 2021, 10, 2037. https:/ / doi.org/10.3390/electronics10162037

Academic Editor: Md

Alamgir Hossain

Received: 24 July 2021

Accepted: 15 August 2021

Published: 23 August 2021

Publisher's Note: MDPI stays neutral with regard to jurisdictional claims in published maps and institutional affiliations.

Copyright: (c) 2021 by the authors. Licensee MDPI, Basel, Switzerland. This article is an open access article distributed under the terms and conditions of the Creative Commons Attribution (CC BY) license (https:/ / creativecommons.org/licenses/by/ $4.0 /)$.

\begin{abstract}
Various power generation technologies, such as wind turbines and solar power plants, have been increasingly installed in renewable energy projects as a result of rising demand and ongoing efforts by global researchers to mitigate environmental effects. The sole source of energy for such generation is nature. The incorporation of the green unit into the power grid also results in volatility. The stabilization of frequencies is critical and depends on the balance of supply and demand. An efficient monitoring scheme called Load Frequency Monitoring (LFM) is introduced to reduce the frequency deviation from its natural state. Specific energy storage systems may be considered to improve the efficiency of the control system. The storage system contributes to the load rate, peak rushing, black start support, etc., in addition to high energy and rapid responsive features. A detailed study of different power storage systems, their current business scenario, and the application of LFM facilities, as well as their analysis and disturbance, is presented in this paper. According to the literature analysis, the current approaches can be divided into two categories: grid and load scale structures. This article also distinguishes between the organized aggregate system and the uncoordinated system control scheme, both of which have advantages and disadvantages in terms of technology.
\end{abstract}

Keywords: load frequency controller; load scale system; battery energy storage; grid-scale system

\section{Introduction}

In the interconnected power system for smooth and stable operation, the balance between production and demand for load should be preserved. In accordance with the frequency deviation and the interfacial power change, the balance is directed at the planned level known as the power of the ties in the respective control areas. The frequencies and power difference of the tie line should be maintained; otherwise, this would threaten the overall stability and durability of the power structure [1-3]. The balance between production and demand is disturbed by one or more production units (also known as generation side) or abrupt changes in connected loads. The short-term loading technique is available daily for this type of scenario and cannot be expected much before the day ends $[4,5]$.

In recent years, renewable energy sources have increased to a high level, thus challenging the generation-demand balance [6]. In addition, renewable energy generation has been increasing. To maintain this balance, the power structure, therefore, has used three different control schemes. The control vector is referred to as the "balancing authority" in accordance with the North American Electric Reliability Company (NERC). There is a certain time frame for the control systems applied to the power system, as shown in Figure 1 [7]. Its main objective is to curb the fluctuation in frequencies and the power tie-in at the control area as well as to maintain a constant power fluctuation in the prescribed 
limits. The minute-to-minute control used for limiting the frequency to a nominal value followed by interruptions is normally known as LFM [8].

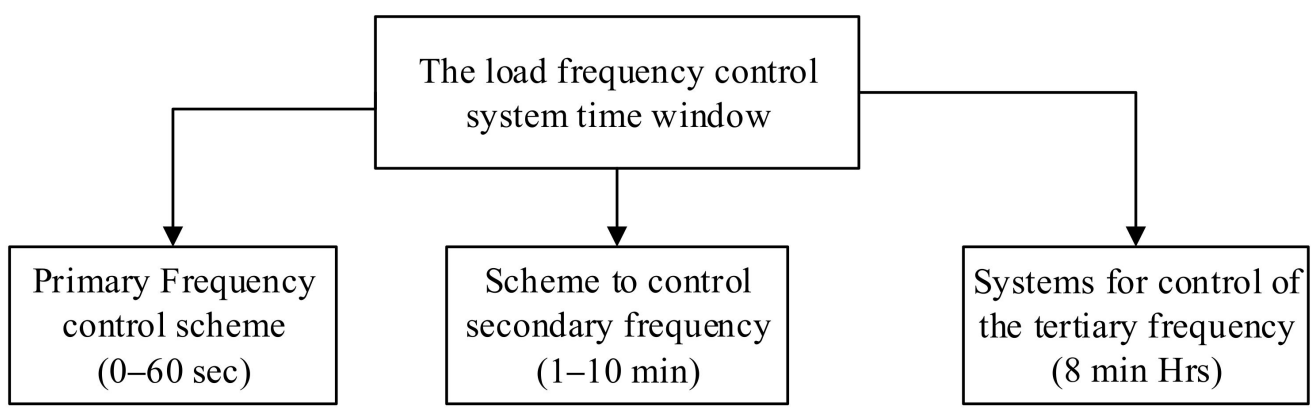

Figure 1. LFM Control scheme specified time window.

Various power plants that are operated synchronously with the power supply grid are controlled and coordinated in conventional LFM control, either partially or fully. The power plant works to converge the control error to null. However, the LFM faces some economic and practical challenges due to partial loads [9-12]. These include high operation and maintenance costs and reduced efficiency. Furthermore, LFM requires 1-10 min because various mechanical links are connected, which is not sufficient to address the above-mentioned challenges. As a result of the research, several control schemes for improving the LFM have been proposed so that the power generation and demand are not suddenly disrupted. The use of fast-acting energy storage elements in the power system is a useful method for overcoming these disturbances. A wide range of storage technology is compatible with the LFM control, including power storage, flywheel, heat storage, and battery storage. Moreover, battery storage is adaptable and makes it a significant player in frequency control applications with advanced electronics systems. A literature survey shows that a lot of work is carried out by many researchers in the areas of energy storage and flexible ac transmission (FACT). The majority of the papers looked at various power system models, their management, and other dynamic aspects, and some papers focused on frequency control energy storage management. As a result, the authors of this paper set out to investigate the various storage systems in their class, as well as the technical aspects of current strategies. The current energy storage scenario is discussed in several advanced and underdeveloped countries, such as the U.S., Japan, China and India. Lastly, the use by frequency regulation of storage and control mechanisms is incorporated in the paper. The paper is organized in the following sections as follows: Section 1 presents the study and comparison of different energy storage technology technical features, followed by Section 2, which presents scenarios of management of energy storage in various parts of the world, and Section 3, which presents energy storage system (primarily battery storage) applications and control strategies in the frequency regulation process. Sections 4 and 5 present the topic and final conclusion of this paper, respectively.

\section{Technology for Storage}

\subsection{Pumped Hydroelectric Storage System (PHSS)}

One of the leading energy storage systems is pumped hydroelectric storage and characterized by high long-term storage of energy [13-15]. PHSS is present worldwide but is mostly found in countries such as Japan $(24.6 \mathrm{GW})$, the United States $(21.8 \mathrm{GW})$ and the least in the European peninsula (6 GW). In a standard PHSS, two tanks are built, with a head maintained between them to convert potential water energy into kinetic energies and turbines. However, during peak hours, water for a pump back system is pumped back into the main reservoir [16-18]. Generally, an increase in the standard hydroelectric station is the pump back system. Thus, by applying the pump system back to the conventional hydro system, the efficiency of the total units is increased [19]. PHSS has a number of advantages, including a long run time, a rapid start, and extremely dependable and efficient power and 
frequency operating controls under up-down conditions. Unfortunately, PHSS includes large upfront expenses, as well as a longer construction phase and a longer reimbursement period. However, with the support of governmental and other organizations, PHSS is certainly profitable and can be used for flood control and irrigation [20].

\subsection{Compressed Air Energy Storage (CAES)}

CAES is an emerging energy storage system for a short or long time. It consists of three stages: compression, storage, and expansion [21-23]. Therefore, in the quantity of storage, the geographical topology of the site is of crucial importance. In certain cases, CAES is used to maximize efficiency with a gas power plant $[24,25]$. Even researchers have produced advanced technologies in the cryogenic mode for the purpose of generating more energy without wasting energy. It offers many PHSS advantages, such as high reliability, high efficiency and long lifetime. Table 1 also shows that the CAES delivers high levels of volumetric volume, mass power, and power, compared to PHSS [26]. In the recent scenario, very little profit was appreciated, despite the various benefits of this storage. There is, therefore, still a major question of commercial viability [27].

Table 1. General storage system specifications for pumped, compressed air and flywheel.

\begin{tabular}{cccc}
\hline Specification & $\begin{array}{c}\text { Pumped-Storage } \\
\text { Hydropower }\end{array}$ & $\begin{array}{c}\text { Compressed-Air } \\
\text { Energy Storage }\end{array}$ & $\begin{array}{c}\text { Flywheel Energy } \\
\text { Storage }\end{array}$ \\
\hline Particular Power & $0.2-0.35$ & $1.7-30$ & $250-25,000$ \\
{$[\mathrm{~W} / \mathrm{kg}]$} & {$[13,15]$} & {$[21,23]$} & {$[28-32]$} \\
\hline Power Density & $0.12-0.45$ & $0.01-8$ & $35-4000$ \\
{$\left[\mathrm{~kW} / \mathrm{m}^{3}\right]$} & {$[13-15,18]$} & {$[24,26]$} & {$[29,30]$} \\
\hline \multirow{2}{*}{ Efficiency [\%] } & $52-74$ & $54-78$ & $65-85$ \\
& {$[17-19]$} & {$[23,25]$} & {$[28,32]$} \\
\hline \multirow{2}{*}{ Scale [MW] } & $20-6000$ & $0.03-4200$ & $0.02-12$ \\
& {$[13,17]$} & {$[22,24]$} & {$[28-30]$} \\
\hline Self-Discharge Rate & 0 & 0 & $20-50$ \\
{$[\% /$ day] } & & 0 & {$[28,29]$} \\
\hline \multirow{2}{*}{ Lifespan [yrs] } & $10-50$ & $5-25$ & $5-20$ \\
& {$[13,15,17-19]$} & {$[23,25,26]$} & {$[28-30]$} \\
\hline Power Capital Cost & $500-7122$ & $450-2122$ & $20-500$ \\
{$[$ US\$ $/ \mathrm{kW}]$} & {$[13,14,16,19]$} & {$[23,24,26]$} & {$[30,32]$} \\
\hline \multirow{2}{*}{ Application } & advanced level of & advanced level of & intermediate level of \\
& Energy Management & Energy Management & Power quality \\
\hline
\end{tabular}

\subsection{Flywheel Energy Storage Unit}

Flywheel energy storage unit (FESU) is an ancient energy storage technology that stores energy in the form of rotary motion. The Flywheel energy storage unit is a common power supply that is virtually unimpaired by a normal temperature drop [28-31]. A recent study has shown that the efficiency of the FESU sub-system can be improved through modernization. However, for the grid connection mode, FESU is still under development. The FESU is now used in the locomotive regenerative locomotive break-up system [32], which generates electricity through braking. The FESU's advantages include high energy and density, quick operation, long service life, temperature invariance, and low maintenance.

\subsection{Thermal Energy Storage}

Thermal energy storage may be used for grid applications in solar power towers at shifting time [33-35]. The change in time means an increase in the conversion rate and the associated thermal alternator power conversion device [36-38]. Different types of 
thermal storage specifications are shown in Table 2. The high energy/power density and low discharge rate as shown in the table below are very effective mechanisms for the grid management system.

Table 2. Diverse thermal energy storage specifications.

\begin{tabular}{|c|c|c|c|}
\hline Specifications & Applicable Heat & Useful Heat & Reaction Heat \\
\hline Explicit Energy [J/kg] & $36,000-432,000$ & $540,000-900,000$ & 900,000 \\
\hline Specific Power [W/kg] & - & $10-30$ & - \\
\hline Power Density $\left[\mathrm{kW} / \mathrm{m}^{3}\right]$ & - & - & - \\
\hline Efficiency [\%] & $10-94$ & 78-95 & $81-92$ \\
\hline Lifespan [yrs] & $6-25$ & $12-34$ & - \\
\hline Scale $[\mathrm{kW}]$ & $1-10,000$ & $1-300,000$ & $10-1$ \\
\hline $\begin{array}{c}\text { Energy Capital Cost } \\
\text { [Rs./kWh] }\end{array}$ & $2.99-3739.49$ & $224.37-6636.10$ & $815.21-10,246.21$ \\
\hline $\begin{array}{c}\text { Power Capital Cost } \\
{[\text { Rs. } / \mathrm{kW}]}\end{array}$ & $186,974.63-590,839.82$ & $14957.97-22,436.96$ & - \\
\hline Application & $\begin{array}{l}\text { intermediate level } \\
\text { Bridging Power }\end{array}$ & $\begin{array}{l}\text { intermediate/ } \\
\text { High-level Energy } \\
\text { Management }\end{array}$ & $\begin{array}{c}\text { Lower/ } \\
\text { intermediate- } \\
\text { level Energy } \\
\text { Management }\end{array}$ \\
\hline
\end{tabular}

\subsection{Battery Energy Storage Unit (BESU)}

The best efficient and broadly used electricity storage device is chemical batteries. Table 3 illustrates the different physical characteristics of batteries, including zinc silver oxide, lithium-ion, lead-acid and alkaline [39-41]. The efficiency of a traditional battery depends greatly on the electrical materials used. However, cycle life and battery life are based on the composition and stability of the used electrolyte. The temperature variation, environment, and charge-unloading regime, therefore, affect the majority of the battery. One of the batteries, zinc silver, is known for flat release, low temperatures and climates and its high strength (ZnAg) [42]. The performance of the electrode (zinc) material is higher than other batteries, but the cost is high. Thus, the battery presence of ZnAg battery is limited in smaller applications, such as hearing aid devices and clocks [43], and is thus not suitable for large-scale storage applications. Its internal resistance is low or high, but its low-temperature driving performance is low-current, and the increasing demand leads to ground contamination problems because its materials recover from the soil at a low zinc, manganese and stain recovery rate [43-47].

The choice of a battery energy storage unit is important for a stationary energy storage application. Moreover, the working mechanism of the polymer membrane cell (PEMFC) is similar [48]. It features remarkable features, such as stability, energy-free size, flexibility, reduced environmental impact, high discharge depth, etc. makes it ideal to support power generation by non-conventional power sources. The use of lithium-ion batteries over recent years has brought many advantages: low cost, reasonable processing time, high cell strength, excellent efficiency at low temperatures, long service life [49,50]. In addition, by using a Li-ion battery [5], researchers are focused on the storage management of plug-in (PEV) hybrid vehicles. In [51], a novel technology of EV wireless charging, which facilitates the on-move charging, can represent another important storage system, given the high number of EVs. 
Table 3. Diverse battery storage system general specification.

\begin{tabular}{|c|c|c|c|c|}
\hline Particulars & Lithium-Ion & Zinc-Silver-Oxide & Lead-Acid & Alkaline \\
\hline Explicit Energy [Wh/kg] & $30-300$ & $81-276$ & $10-50$ & 80-175 \\
\hline Energy Density $\left[\mathrm{kWh} / \mathrm{m}^{3}\right]$ & $94-500$ & $4.2-957$ & $25-90$ & $360-400$ \\
\hline Specific Power [W/kg] & 8-2000 & $0.09-330$ & $25-415$ & $4.35-35$ \\
\hline Power Density $\left[\mathrm{kW} / \mathrm{m}^{3}\right]$ & $56.8-800$ & $0.36-610$ & $10-400$ & $12.35-101.7$ \\
\hline Efficiency $[\%]$ & $70-100$ & $20-100$ & $63-90$ & $36-94$ \\
\hline Lifespan [yrs] & $2-20$ & $2-1$ & $3-20$ & $2.5-10$ \\
\hline Cycle Life [cycles] & $250-10,000$ & $1-1500$ & 100-2000 & $1-200$ \\
\hline Self-Discharge Rate [\%/day] & $0.03-0.33$ & $0.01-0.25$ & $0.033-1.1$ & $0.008-0.011$ \\
\hline Scale $[\mathrm{kW}]$ & $0-3000$ & $0-250$ & $0-50000$ & $0-1$ \\
\hline Energy Capital Cost [Rs./kWh] & $14,957.97-299,159.40$ & $236,859.45-1495,797.00$ & $3739.49-82,268.84$ & $7478.99-74,789.85$ \\
\hline Power Capital Cost [Rs./kW] & $13,088.22-4000$ & $74,789.85-889,999.21$ & $13,088.22-67,310.87$ & $74,789.85-889,999.21$ \\
\hline Application & $\begin{array}{c}\text { Lower/intermediate } \\
\text { level Energy } \\
\text { Management }\end{array}$ & $\begin{array}{l}\text { Lower level } \\
\text { Energy Management }\end{array}$ & $\begin{array}{c}\text { Lower/intermediate } \\
\text { level Energy } \\
\text { Management }\end{array}$ & $\begin{array}{l}\text { Lower level } \\
\text { Energy Management }\end{array}$ \\
\hline
\end{tabular}

\subsection{Simple Conduction and Supercapacitor Magnetic Energy Storage}

In processing and storing systems, such as storage voltage and synchronous generators, superconductors are very common [52-54]. Indeed, the Super-Leading Magnet Energy Stock (SMES) was developed with supranational properties. The main aim is to provide relatively high power quality for a shorter time period [55]. Since it was observed, maximum grid failure numbers are due to sag and failures that last less than one second. SMES is highly effective for faster operations and energy quality problems with grid applications. In addition, SMES aims to control the reparation slope and power quality, which are expected to range from 10 to $1000 \mathrm{MW}$ by 2040 [7].

Sometimes, the super condenser is called an electric condenser of dual layer and is commonly used as a secondary primary system in hybrid-powered vehicles [56]. The efficiency rates are high, the charge period is faster, and internal losses are low [57]. Consequently, it is mostly used for slope compensation in grid operations. Although they are expensive, the SMES and super condensers are almost maintenance free. The SMES and super condenser's technical specifications are presented in Table 4. The cost of a superconductor is expected to decline gradually with several manufacturers entering the market $[58,59]$.

Table 4. Diverse SMES and super-capacitor storage devices specifications.

\begin{tabular}{ccc}
\hline Particulars & Superconducting & Super-Capacitor \\
\hline Explicit Energy [J/kg] & $972-270,000$ & $252-308,160$ \\
\hline Explicit Power $[\mathrm{W} / \mathrm{kg}]$ & $300-12,000$ & $6.32-200,000$ \\
\hline Power Density $\left[\mathrm{kW} / \mathrm{m}^{3}\right]$ & $500-3000$ & $14-3400$ \\
\hline Efficiency [\%] & $78-94$ & $63-94$ \\
\hline Lifecycle [yrs] & $20-30$ & $4-23$ \\
\hline State of Charge [\%/day] & $1-22$ & $0.43-50$ \\
\hline Capacity [MW] & $0.02-300$ & $0-4$ \\
\hline Energy per capita Cost [Rs./kWh] & $29,930.62-7,931,614.30$ & $7482.65-6,210,603.65$ \\
\hline Power per capita Cost [Rs./kW] & $13,842.91-748,265.50$ & $7482.65-59,861.24$ \\
\hline Application & intermediate/Higher level & Low /intermediate level \\
Power Quality & Power Quality
\end{tabular}




\section{World-Wide Storage Scenario}

\subsection{United States of America}

The U.S. has developed carbon-storage technology $[60,61]$ and is one of the most developed countries. The first battery was developed by Volta in 1800, and Volta Cell was also the first power storage device founded in 1929 on the Housatonic River in Connecticut's Rocky River. In the U.S., $41 \%$ of projects are operational, and 33\% are being built. California is the leading country, with 220 operational $4.2 \mathrm{GW}$ power projects, followed by Virginia and South Carolina. Energy storage in the U.S.A. increased more rapidly from 2013 to 2018, by $174 \%$, in various measures between the government and the local agency [62].

\subsection{Japan}

As of 2018, 1361 projects [60] were completed. In the United States, $41 \%$ of projects are operational, while $33 \%$ are under construction. California is the leading country with 220 power plants, followed by Virginia and South Carolina with $5.3 \mathrm{GW}$ each. The PHES (3.68 GW), BES (0.75 GW), CAES (0.114 GW), and FESU $(0.058 \mathrm{GW})$ were the maximum energy storage amounts (94\%) of the total installation, as of December 2020. As the U.S. now builds the largest battery storage system, Japan continues to be the world leader in battery storage. In addition, Japan plans to expand half of the global storage sector by 2025 . Since 1990, the installation of NaS batteries has increased more quickly, as the data reveal. In 1998, the rating was only $10 \mathrm{MW}$, but in 2009, $300 \mathrm{MW} / 2000 \mathrm{MWh}$ and, in the following year, $350 \mathrm{MW}$, were achieved.

\subsection{China}

In addition to the continued growth of additional services and sustainable grid investment through smart grid development, the energy storage progress in China has increased faster [63]. Recently, the cost of lithium-ion batteries decreased by up to $50 \%$, compared to the past. In 2019, Jin Jiang Province of Fujian implemented the first and largest electro-mechanical power plant in China with a virtual synchronous generator [64]. The system provides a battery power storage capacity of 100 MWh with $400 \mathrm{MW}$ integrated wind, $200 \mathrm{MW}$ photovoltaic and $50 \mathrm{MW}$ of a concentrated PV system. The rating of the system will increase to $1000 \mathrm{MWh}$. In the next phase, government reforms will promote nationwide storage system development and further build the system's capacity [65].

\subsection{India}

The anticipated reforms and stimulus of the government are only just starting India's storage industry [66-68]. Renewable energy battery storage systems are allowed at $6000 \mathrm{MW}$ [69-72]. The new energy storage range is predicted to be significantly higher than the existing unit by 2022, as the government will expand renewable energy production to $175 \mathrm{GW}$. In addition, 20,000 micro-networks/400 MW of microns and mini-networks will be integrated into the current system [73]. Therefore, there are much more options in storage systems if the abovementioned goal is fulfilled.

\section{Overview and Use of LFM Energy Storage}

Since the early 1900s, power system applications have been used for energy storage battery technology. In [74], the authors discussed how to match battery and tested Indiana Traction Company's sub-stations in 1902. The use of storage, for example, can be 2-3 times more efficient than the introduction of frequency rules for combustion units [75]. The hierarchical description of power storage use is shown in Figure 2. One method of this type is the management of frequencies; the Battery Energy Storage Unit (BESU) has been used for decades. When the frequency exceeds the program, the charging mode is the battery. Furthermore, under these conditions, BESU will deliver electricity to the grid when the level falls below the planned value, called the discharge mode. In addition, researchers considered the concept to be applied for smart grid systems [76-78]. 


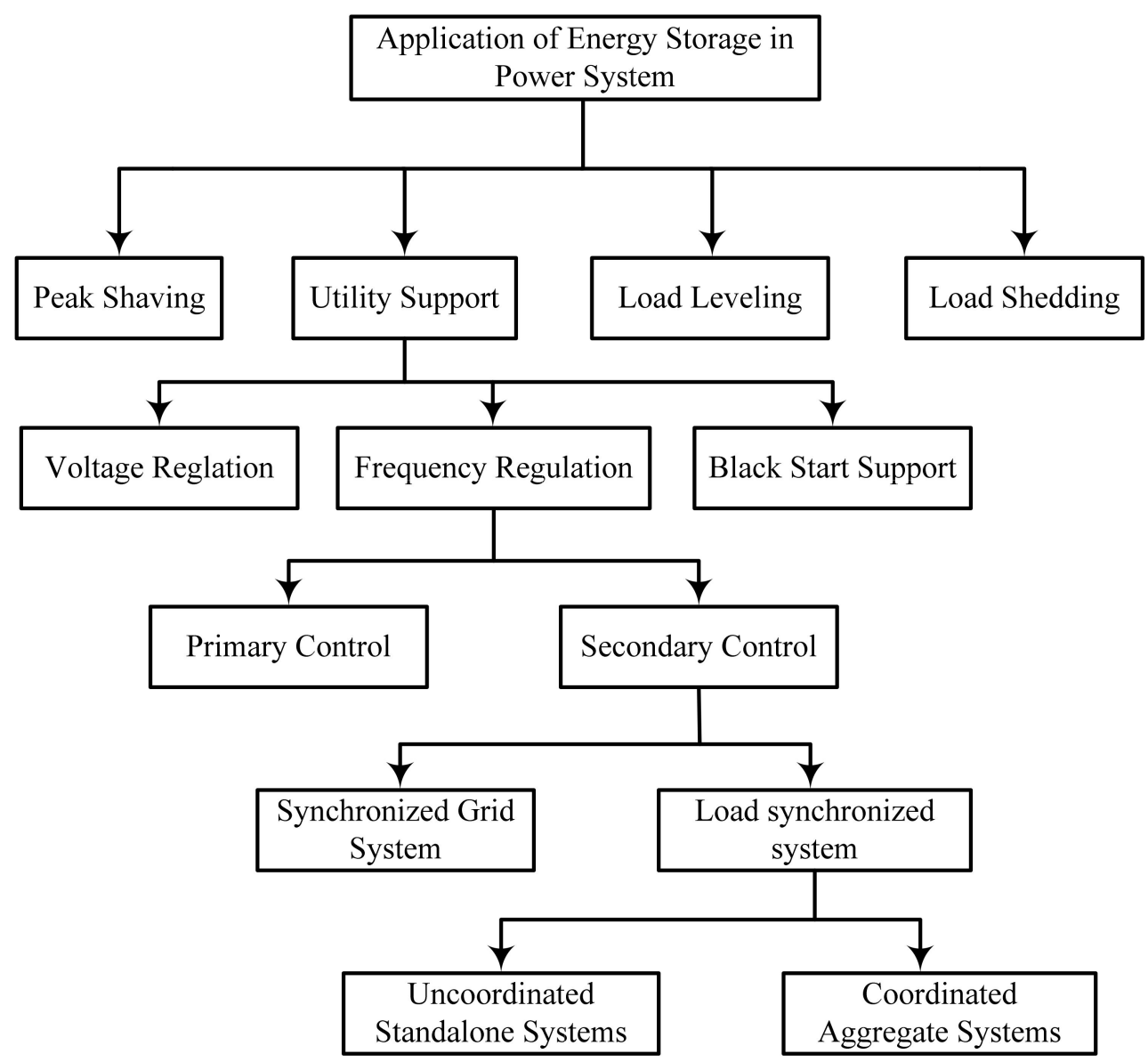

Figure 2. Flow chart showing energy storage application in power system.

In Figure 3, a program to control LFM by power storage technology is defined [79]. Based on the volume of the power storage, position and grid control, efficiency, and activity, two types of systems are implemented through different shipping systems.

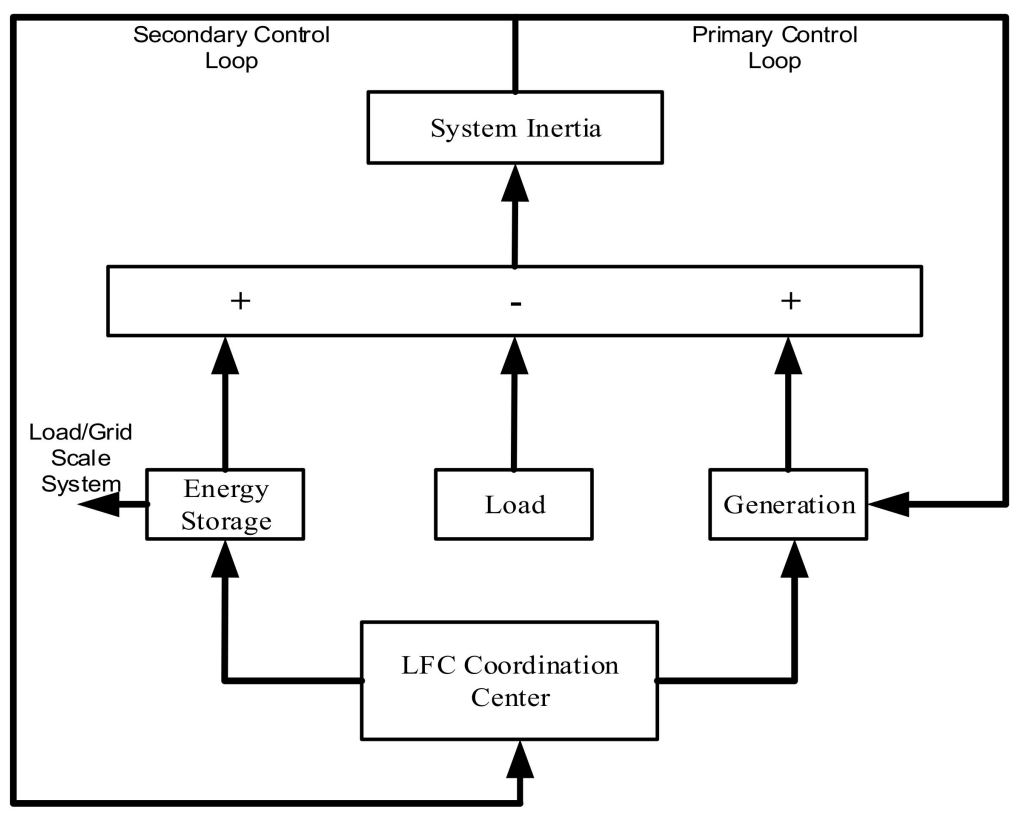

Figure 3. Line diagrams show the LFM single area system coordination. 


\subsection{System of Grid Scale}

In this type, LFM is used to control centralized battery systems and the modern reheating type is considered. In 2001, two BESU interconnected power systems were used with LFM with a heat heating plant. A $1 \%$ increase was observed on the market for the device in the simulation test. In addition, in the MATLAB simulation environment, the LFM performance of the two-area connected system was simulated by [80-84]. BESU was used in [85] to improve the system's LFM performance. The impact of BESU on LFM was achieved in an isolated power system for the optimal size of BESU. The BESU results for one month of operation were inspected by MATLAB. The frequency deviation without BESU was observed to be $0.98 \%$ (scheduled $50 \mathrm{~Hz}$ ), while the deviation with BESU was only $0.18 \%$.

In a multi-microgrid system, the idea of integration of BESU as a part of a distributed system can be accepted [86]. A multi-microgrid with two micro grids was observed, which are interconnected. In this case, a two-ACE multi-microgrid frequency control was used. Wind turbine generators, supporting batteries, and hydro plants are all housed in an insulated system. The LFM's chrematistics was tested with and without the energy storage element. The BESU's power rate was demonstrated to be $53 \%$ lower.

\subsection{LFM Control Schemes}

- For future studies, the LFM schemes are important. LFM control systems are inevitably used in Automatic Generation Control (AGC). Depending on the device condition, the control signal of LFM connecting units is activated. For further information on LFM control schemes, [87] may be referred to. The LFM controllers are classified as two different types:

- Classic control system: a linear quadratic controller, proportional integral derivative.

- Control system for artificial intelligence (AI): this includes a fuzzy optimization scheme, genetically modified and hybrid.

A battery energy system can be used to improve the BESU LFM system in all types of control procedures. In this case, the controller will send the signals to the assisted BES and LFM units. In addition, in the literature survey, multi-stage monitoring, fractional controls and cascade controllers were recently used in an LFM survey [88-91]. In [92-94], the authors considered a robust control technique, H-infinity. The authors investigated, presented and discussed topics, such as uncertainty in parameters and diffusion delays. The control system introduced by the LFM two-area New England 39-bus network was examined. This gave the controls of $\mathrm{H}$-infinity greater stability and robustness than the PI controller.

\subsection{BESU Characteristics}

In general, in a battery storage system, there are three basic modules [95]:

- Battery set: the sequence or simultaneous group of battery cells.

- Module for power supplying: power electronic converters are used to attach BESU to the grid.

- Control and protection: this maintains the state of charge (SOC) track and confirms that battery capacity regulates battery charge with regard to the control system variable used for safety and safety in applications. Discharge of the battery charge is necessary. In [96], the authors noted, in several applications, diverse batteries, their merit and demerits. Battery capability, charging and discharge speeds, long evenness, and SOC restrictions for different types of batteries play an important role in the success of the LFM [97]. Two types of secondary batteries are usually used in power systems:

- Classical battery: includes sodium-sulfur, lithium-ion, cadmium-nickel, acid-lead.

- Battery flow: vanadium redox characterized.

Sodium-sulfur is the most efficient battery technology used mainly in the grid [98]. In comparison with other battery types, however, production costs for lithium batteries 
are high. The use of the sodium battery system is introduced in [99]. A control method for H-infinity controllers was developed. In both areas, there is a significant reduction in fluctuations in production with the sodium sulfur battery system. In utilities, flow batteries between several rechargeable batteries are reliable. However, the redox batteries have complex, costly and low energy densities in contrast to traditional batteries. In Charging Frequency Control, the 120 redox battery is utilized. By simulating interconnected systems in two fields, the authors examined the RF's battery efficiency and their benefit. Both hydroelectric and thermal battery generators feature connected systems. In the aforementioned works, the authors clarified the LFM device with one battery. However, the effects of different characteristics of various BESU sets were not discussed. There was discussion in [99] on the use of various BESU sets. The authors invented advanced SOC-based control systems, taking up and unloading characteristics. For this study, two sets of batteries with different capacities of sodium-sulfur and nickel-metal hydrides were considered and examined. Despite the variation in the charge-unload rate of the used battery, the simulation results show that the LFM system's performance has improved.

\subsection{Optimum Size of BESU}

The quality of the BESU system is one of the major problems in the supply chain of the BESU location. Authors in [100] declared that, before taking account of the BES price, it is necessary to weigh up the complexity of the BESU scheme. Thus, great profitability in the system can be achieved by optimizing the size of BESU. Moreover, the battery size is chosen primarily so that the LFM power and energy demand can be satisfied. The optimum BESU sizing should, therefore, be performed. This field was worked on by authors from [101-103]. The variations in the response speed between the battery and the LFM devices must be considered before determining the size of the battery. Similar methods of reducing thermal unit rates and critical power for BESU were developed in [85]. An LFM strategy through the implementation of the BESU was discussed in [100], in light of the reduced BESU capacity. A variation in the thermal system and BESU reaction speed was observed by the authors in the division of the LFM duty. The system's frequency of thermal equipment is controlled by the BESU units during the load flow. Therefore, quick BESU does not remove thermal units, and limits loading and unloading. This significantly reduces the BESU's energy capacity [75]. LFM signals are obtained through the battery storage power deviation on a line. This can be useful if the thermal unit's output does not depend on BESU. The capacity of BESU was shown to be cut to 30\%. In [98], authors proposed a method for optimizing the size of BESU for operating revenues by using the Net Present Value formula.

\subsection{Numbers of Grid-Scale Systems}

The entire review of work in this category was based on the use of lateral control and the connected BESU system in large-scale systems [52-54]. In the power system, this method is the most popular. It described below the following practical challenges:

- Large-scale BESU systems' cost installation.

- In BESU systems, high efficiency is needed.

- The variance in the time scales between generating units and BESU units is required for a correlational transmission of LFM signal between therapeutic units, the system operator and BESU.

Today, by managing frequencies and distributing the obstacle, we are paying more attention to side controls. The authors have noted this in [70], stating that the capacity of BESU can effectively be further reduced by battery storage charges. Various BESU LFM methods and local charges are defined in the following section as regulated reservations.

\subsection{Load Measurement System}

In the event of changes to the frequency in the generating, transmitting, or distributing systems, an effective method to affect load generating balance is immediately recognized 
and measured [74]. The loads play an essential role in controlling the system frequency instead of being in the grid [74]. The role of frequency loads is first described in this section before different LFM control schemes are discussed. Many papers were produced in this field [76]. Loadings, such as hot pump water heaters, cooling heaters and heaters, are ideal because thermal energy is retained [78]. In [87], LFM assistance was used for thermal energy storage with water heaters. The ON-OFF switch can be used to control this type of charging over a short period. For device control, this controller monitors line frequencies. When the frequency in India is lower than usual, the load reduction controller turns off the devices in a matter of seconds to minutes.

In [87], the authors showed a program to monitor the system frequency of the distributed load control, thereby reducing the inutility of the load. To solve this problem, a group of devices should be set up to turn off if the frequency falls below a certain threshold. For ON-OFF switching appliances, a control algorithm is required so that user preferences are not disrupted. In [92], the ON-OFF plan was proposed for devices, allowing main reserves in both directions, considering three types of user choice conservatives and optimists. A new theory, called "Electric Spring", was developed. These authors have used electronic devices for the creation of a concept of "intelligent charges".

The controlled programs mentioned above do not fall under our review because the use of battery storage in the regulation of frequencies was explicitly discussed. There is, therefore, a focus here on the demand side of BESU. Customers can use battery storage to improve the LFM control. It falls under the category of loading system, according to our classification. The scattered storage system is installed on the charge side for secondary storage and is often operated in similar ways to AGC, depending on the available data, for thermal generation. The application currently uses and mainly discusses electric vehicles. There are various types of U.S. electric vehicles ("Hybrid and Plug-in Electric Vehicles"). Various researchers have proposed the use, through technology growth, of such electric vehicles on LFF's BESU mobile platform [97]. The load network system can be split into two forms based on the form of the power systems connected to the managed loading units: the collective synchronized system, and the individual non-synchronized system.

\section{Future Work}

In the following subtopic, further analysis is necessary to create a viable energy storage technology management plan for hybrid energy.

\subsection{Synchronized Combined System}

The integrated device plays a decisive role, as with any other load scale system. The innovative devices to be used for this program are electric cars. Authors in [98] stated that other systems can be easily used for the storage of the distributed battery energy, such as the domestic battery banks or the battery equipment. A manager and intermediate controller was deployed (known as the aggregator), which gathers the batteries SOC information, and on and off time [34]. We even measured how powered and ultimately connected electric vehicles and smart interfaces are to a dispatch center. LFM signals were then transmitted, using the aggregator to electric vehicles [55]. In order to satisfy their consumers, this SOC scheme only regulates plugged, fully charged electric vehicles at a level of $80-90 \%$. This plan proposes that in 500 local control centers, 50,000 electric cars be installed in the main loading center. Two criteria were used to test the program, which either took user convenience or did not take user convenience into account. The result is that, in the event of the consideration of user expediency, the frequency response is better than when the expediency of the user is not considered. The second example is SOC limits for tracking electric vehicles' performance. The authors suggested that the BESU, a district of plug-in thermostat-regulated hybrid electrical vehicles, be used to control the LFM control system. In a management system known as a model based on aggregator prediction control $[56,57]$, the authors invented an aggregation method. The proposed model is a pack of 40,000 plugs for electric vehicles, thermo-controlled equipment and a CHP platform 
that is connected to an urban network with 160,000 people. The findings show that the LFM system develops successfully these frequency management techniques. On the other hand, as suggested, the speaker questions the availability and need for reserve amounts for realistic program. Moreover, the performance of aggregations was discussed in view of the quick communication and the result of a delay in the communication system. The effect of grid and LFM load communications and data exchanges was discussed in [58]. The authors finally ignored the delay in the network. The model was operated by an $8000 \mathrm{MW}$ random charge change and a large $1800 \mathrm{MW}$ wind power impact. They also suggested different transformation delays and changes in the battery storage rate. Another problem is that SOC limits are considered to prevent overcharge or batteries being discharged [65-67]. The authors addressed SOC limit issues by developing an energy distribution network that changed the smart grid frequency using the Hierarchical Model Prediction Distribution [37]. The model proposed includes conventional generators, coordinated electric vehicles and renewables. LFM showed a significant increase in efficiency [76,77], in contrast to hybrids that cannot be driven by electric motors.

In [77], the authors discovered a new controlling system with the V2 G frequency support system. The main goal is to deal with system complexities and perturbations, as well as to create a simple and stable controller. The $\mathrm{H}_{2} / \mathrm{H}$ infinity control system was used to implement a particle swarm optimization process [78], and both conventional and intelligent control systems were used to control the controller frequency parameters. As a PI controller, the frequency controller was used. In order to keep the battery SOC within the set range, the SOC optimization method was used to control the power output of the battery. The effectiveness and heftiness of the control system were determined, using the results of a two-area wind turbine simulation.

The following are the issues that must be resolved based on our discussion:

- The charge-discharge system will strike a balance between the consumer's needs and appropriateness.

- To accomplish this, system controllers should be capable of managing and tracking several loads. For the dispatch of LFM signals and interconnections with generating units, intermediate control and aggregation systems are, therefore, required.

- The aggregator analyzes the appropriate LFM resources from local operating systems without understanding the state of the entire network. The calculation, modification and collection of real-time load conditions, for example, the size, duration, plug and charge of the battery SOC [79], are the way to achieve this.

The cost of installation and maintenance of the system will increase if the above systems are implemented. Utility operators must, therefore, adhere to this load management regime in order to achieve the best possible balance of capacity control, cost, communication, and frequency regulation effectiveness.

\subsection{Non-Synchronized Combined System}

Currently, the field of power control schemes is developing rapidly. To achieve load lateral frequency control, it has yet to be implemented the theory of unregulated control of each charge with battery energy storage. In a synchronized combined system, electric vehicles play an important role, where decentralized regulation is achieved via battery chargers at the end of the electric vehicle. Therefore, intelligent interface circuits are needed, which control the two-way current between the power supply and the battery as well as the frequency measurement.

In [74], as mentioned by the author, the primary objective of the discrete unregulated system is to spread the cybersecurity and communication requirements across system operators and controlled loads so that the system is flexible. In [86], the author stated that this scheme is the same as loading and grid responses controllers controlled by frequency. A drop control system corresponding to the generator drop control was used to regulate the charging-discharge process of the charged battery power storage so that the equipment does not have to be switched off during the period under frequency. 
It was found in the literature that numerous efforts have been made. The performance of the lithium-ion battery was examined by the authors [85]. The energy efficiency and the battery cycling capacity were assessed from the results obtained from the simulation. The decentralized control algorithm of domestic batteries was discussed by different authors [89-91]. The central organizations aim to prioritize customer suitability for SOC criteria and to maintain their privacy by increasing exchange prices for their device operators.

\section{Conclusions}

Energy storage provides reactive power compensation, suppression of unbalancing, load grading and energy balance, particularly where the electricity system includes multiple renewable energy sources. Energy storage is essential to improve the power quality. It also provides substantial technical and economic support for the stability of the system. This procedure can be implemented with a wide range of storage units managed through the LFM utility. This system is required by both the operator and the service provider to maintain the highest level of precision and cost control. Electric vehicles not only assist in the regulation of frequencies, but also serve as an efficient energy storage system. The Tesla Power Wall and Nissan Stocking are two examples of efficient and advanced batteries that can be used to store energy. EVs will play an important role in the near future in terms of energy, with high-energy stock technology. Smart grid-based services and app frequency controls could be reasonable; as a result, power technologies could also be promoted. Soon, the world will experience within its roles a new type of mature storage technology.

Author Contributions: Conceptualization, writing-original draft preparation, A.R. and P.K.S.; supervision, writing-review and editing, A.I.; resources, funding acquisition, B.A. All authors have read and agreed to the published version of the manuscript.

Funding: The authors would like to acknowledge the financial support from Taif University Researchers Supporting Project Number (TURSP-2020/278), Taif University, Taif, Saudi Arabia.

Conflicts of Interest: The authors declare no conflict of interest. The funders had no role in the design of the study; in the collection, analyses, or interpretation of data; in the writing of the manuscript, or in the decision to publish the results.

\section{References}

1. Murty, V.V.; Kumar, A. Optimal Energy Management and Techno-economic Analysis in Microgrid with Hybrid Renewable Energy Sources. J. Mod. Power Syst. Clean Energy 2020, 8, 929-940. [CrossRef]

2. Zellagui, M.; Lasmari, A.; Settoul, S.; El-Bayeh, C.Z.; Chenni, R. Assessment Integration of Hy-brid PV-DSTATCOM-BES-DG System in EDS under Uncertainties Using Chaotic Adaptive Inertia Weight PSO Algorithms. In Proceedings of the 2021 12th International Symposium on Advanced Topics in Electrical Engineering (ATEE), Bucharest, Romania, 25-27 March 2021; pp. 1-8.

3. Bihari, S.P.; Sadhu, P.K.; Sarita, K.; Khan, B.; Arya, L.D.; Saket, R.K.; Kothari, D.P. A Comprehensive Review of Microgrid Control Mechanism and Impact Assessmeent for Hybrid Renewable Energy Integration. Access IEEE 2021, 9, 88942-88958. [CrossRef]

4. Kumar, J.S.; Raja, S.C.; Srinivasan, D.; Venkatesh, P. Hybrid renewable energy-based distribution system for seasonal load variations. Int. J. Energy Res. 2018, 42, 1066-1087. [CrossRef]

5. Santos, Y.A.; Nunes, M.P.M.; Lemes, L.A.C.; Bortoni, E.C. Evaluation of Hybrid Energy Storage Systems Using Wavelet and Stretched-Thread Methods. IEEE Access 2020, 8, 171882-171891. [CrossRef]

6. Syed, M.A.; Khalid, M. Moving Regression Filtering With Battery State of Charge Feedback Control for Solar PV Firming and Ramp Rate Curtailment. IEEE Access 2021, 9, 13198-13211. [CrossRef]

7. Fan, Y.; Fang, L.; Xu, M.; Wu, H.; Zhou, Z.; Liu, B.; Lin, S.; Wang, Y. A Transform-er-Less Voltage Equalizer for Energy Storage Cells Based on Double-Tiered Multi-Stacked Converters. IEEE Access 2021, 9, 87630-87642. [CrossRef]

8. Yang, W.; Norrlund, P.; Saarinen, L.; Witt, A.; Smith, B.; Yang, J.; Lundin, U. Burden on hydropower units for short-term balancing of renewable power systems. Nat. Commun. 2018, 9, 2633. [CrossRef]

9. Hajiaghasi, S.; Salemnia, A.; Hamzeh, M. Hybrid energy storage system for microgrids applications: A review. J. Energy Storage 2019, 21, 543-570. [CrossRef]

10. Hesaroor, K.; Das, D. Optimal sizing of energy storage system in islanded microgrid using incremental cost approach. J. Energy Storage 2019, 24, 100768. [CrossRef]

11. Paliwal, N.K.; Singh, A.K.; Singh, N.K.; Kumar, P. Optimal sizing and operation of battery storage for economic operation of hybrid power system using artificial bee colony algorithm. Int. Trans. Electr. Energy Syst. 2019, 29, e2685. [CrossRef] 
12. Sun, Y.; Tang, X.; Sun, X.; Jia, D.; Cao, Z.; Pan, J.; Xu, B. Model predictive control and improved low-pass filtering strategies based on wind power fluctuation mitigation. J. Mod. Power Syst. Clean Energy 2019, 7, 512-524. [CrossRef]

13. Majumder, S.; Khaparde, S.A.; Agalgaonkar, A.P.; Ciufo, P.; Perera, S.; Kulkarni, S.V. DFT-based sizing of battery storage devices to determine day-ahead minimum variability injection dispatch with renewable energy resources. IEEE Trans. Smart Grid 2019, 10, 626-638. [CrossRef]

14. Conte, F.; D'Agostino, F.; Pongiglione, P.; Saviozzi, M.; Silvestro, F. Mixed-integer algorithm for optimal dispatch of integrated PV-storage systems. IEEE Trans. Ind. Appl. 2010, 55, 238-247. [CrossRef]

15. Wen, T.; Zhang, Z.; Lin, X.; Li, Z.; Chen, C.; Wang, Z. Research on Modeling and the Operation Strategy of a Hydrogen-Battery Hybrid Energy Storage System for Flexible Wind Farm Grid-Connection. IEEE Access 2020, 8, 79347-79356. [CrossRef]

16. Vahid, S.; El-Refaie, A. A Novel Semi-Isolated Three-Port dc-dc Power Converter with Soft Switching Technique for Hybrid Energy Storage Applications. In Proceedings of the 2021 22nd IEEE International Conference on Industrial Technology (ICIT), Valencia, Spain, 10-12 March 2021; Volume 1, pp. 278-284.

17. Yu, P.; Liu, X.; Zhang, Y.; Hu, X.; Kong, G.; Zhao, P.; Cheng, Y.; Li, S.; Zuo, X.; Sun, S. Battery-supercapacitor hybrid energy storage system for wind power suppression based on the turbulence model of wind speed. J. Eng. 2018, 2018, 1922-1929. [CrossRef]

18. Asghari, B.; Sharma, R. Cost-aware real-time power management of grid-tied microgrids based on battery life regula-tion. In Proceedings of the 2017 IEEE Manchester PowerTech, Manchester, UK, 18-22 June 2017; pp. 1-6.

19. Gong, Y.; Jiang, Q.; Baldick, R. Ramp Event Forecast Based Wind Power Ramp Control With Energy Storage System. IEEE Trans. Power Syst. 2015, 31, 1831-1844. [CrossRef]

20. Zhou, B.; Zou, J.; Chung, C.Y.; Wang, H.; Liu, N.; Voropai, N.; Xu, D. Multi-microgrid Energy Management Systems: Architecture, Communication, and Scheduling Strategies. J. Mod. Power Syst. Clean Energy 2021, 9, 463-476. [CrossRef]

21. Kroposki, B. Integrating high levels of variable renewable energy into electric power systems. J. Mod. Power Syst. Clean Energy 2017, 5, 831-837. [CrossRef]

22. Hirsch, A.; Parag, Y.; Guerrero, J. Microgrids: A review of technologies, key drivers, and outstanding issues. Renew. Sustain. Energy Rev. 2018, 90, 402-411. [CrossRef]

23. Xu, Z.; Yang, P.; Zheng, C.; Zhang, Y.; Peng, J.; Zeng, Z. Analysis on the organization and Development of multi-microgrids. Renew. Sustain. Energy Rev. 2018, 81, 2204-2216. [CrossRef]

24. Wang, S.; Geng, G.; Ma, J.; Jiang, Q.; Huang, H.; Lou, B. Operational Bottleneck Identification based Energy Storage Investment Requirement Analysis for Renewable Energy Integration. IEEE Trans. Sustain. Energy 2020, 12, 1. [CrossRef]

25. Abdelrazek, S.A.; Kamalasadan, S. Integrated PV Capacity Firming and Energy Time Shift Battery Energy Storage Management Using Energy-Oriented Optimization. IEEE Trans. Ind. Appl. 2016, 52, 2607-2617. [CrossRef]

26. Alves, M.; Segurado, R.; Costa, M. Increasing the penetration of renewable energy sources in isolated islands through the interconnection of their power systems. The case of Pico and Faial islands, Azores. Energy 2019, 182, 502-510. [CrossRef]

27. Nguyen, T.L.; Guerrero, J.M.; Griepentrog, G. A Self-Sustained and Flexible Control Strategy for Islanded DC Nanogrids Without Communication Links. IEEE J. Emerg. Sel. Top. Power Electron. 2020, 8, 877-892. [CrossRef]

28. Monesha, S.; Kumar, S.G.; Rivera, M. Methodologies of Energy Management and Control in Microgrid. IEEE Lat. Am. Trans. 2018, 16, 2345-2353. [CrossRef]

29. Li, Z.; Shahidehpour, M.; Aminifar, F.; AlAbdulwahab, A.; Al-Turki, Y. Networked Microgrids for Enhancing the Power System Resilience. Proc. IEEE 2017, 105, 1289-1310. [CrossRef]

30. Han, Y.; Zhang, K.; Li, H.; Coelho, E.A.A.; Guerrero, J.M. MAS-Based Distributed Coordinated Control and Optimization in Microgrid and Microgrid Clusters: A Comprehensive Overview. IEEE Trans. Power Electron. 2018, 33, 6488-6508. [CrossRef]

31. Shen, Y.; Liang, X.; Hu, W.; Dou, X.; Yang, F. Optimal Dispatch of Regional Integrated Energy System Based on a Generalized Energy Storage Model. IEEE Access 2021, 9, 1546-1555. [CrossRef]

32. Wu, Q.H.; Qin, Y.J.; Wu, L.L.; Zheng, J.H.; Li, M.S.; Jing, Z.X.; Zhou, X.X.; Wei, F. Optimal operation of integrated energy systems subject to the coupled demand constraints of electricity and natural gas. CSEE J. Power Energy Syst. 2019, 6, 444-457. [CrossRef]

33. Gao, X.; Fu, L. SOC optimization based energy management strategy for hybrid energy storage system in vessel inte-grated power system. IEEE Access 2020, 8, 54611-54619. [CrossRef]

34. Madduri, P.A.; Poon, J.; Rosa, J.; Podolsky, M.; Brewer, E.A.; Sanders, S.R. Scalable DC Microgrids for Rural Electrification in Emerging Regions. IEEE J. Emerg. Sel. Top. Power Electron. 2016, 4, 1195-1205. [CrossRef]

35. Chen, X.; Shi, M.; Zhou, J.; Zuo, W.; Chen, Y.; Wen, J.; He, H. Consensus-Based Distributed Control for Photovoltaic-Battery Units in a DC Microgrid. IEEE Trans. Ind. Electron. 2018, 66, 7778-7787. [CrossRef]

36. Huang, A.W.; Qahouq, J.A.A. Energy sharing control scheme for state-of-charge balancing of distributed battery energy storage system. IEEE Trans. Ind. Electron. 2015, 62, 2764-2776. [CrossRef]

37. Guo, F.; Wang, L.; Wen, C.; Zhang, D.; Xu, Q. Distributed Voltage Restoration and Current Sharing Control in Islanded DC Microgrid Systems Without Continuous Communication. IEEE Trans. Ind. Electron. 2020, 67, 3043-3053. [CrossRef]

38. Kumar, D.; Zare, F.; Ghosh, A. DC Microgrid Technology: System Architectures, AC Grid Interfaces, Grounding Schemes, Power Quality, Communication Networks, Applications, and Standardizations Aspects. IEEE Access 2017, 5, 12230-12256. [CrossRef]

39. Vuyyuru, U.; Maiti, S.; Chakraborty, C.; Batzelis, E.I. Universal Active Power Control Converter for DC-microgrids with Common Energy Storage. IEEE Open J. Ind. Appl. 2021, 2, 21-35. [CrossRef] 
40. Morstyn, T.; Hredzak, B.; Agelidis, V.G. Communication delay robustness for multi-agent state of charge balancing between distributed AC microgrid storage systems. In Proceedings of the 2015 IEEE Conference on Control Applications (CCA), Sydney, Australia, 21-23 September 2015; pp. 181-186.

41. Salama, H.S.; Said, S.M.; Aly, M.; Vokony, I.; Hartmann, B. Studying Impacts of Electric Vehicle Functionalities in Wind Energy-Powered Utility Grids With Energy Storage Device. IEEE Access 2021, 9, 45754-45769. [CrossRef]

42. Podder, A.K.; Chakraborty, O.; Islam, S.; Kumar, N.M.; Alhelou, H.H. Control Strategies of Different Hybrid Energy Storage Systems for Electric Vehicles Applications. IEEE Access 2021, 9, 51865-51895. [CrossRef]

43. Li, Z.; Chan, K.W.; Hu, J.; Guerrero, J.M. Adaptive Droop Control Using Adaptive Virtual Impedance for Microgrids With Variable PV Outputs and Load Demands. IEEE Trans. Ind. Electron. 2021, 68, 9630-9640. [CrossRef]

44. Bruninx, K.; Dvorkin, Y.; Delarue, E.; Pandzic, H.; D’Haeseleer, W.; Kirschen, D.S. Coupling Pumped Hydro Energy Storage With Unit Commitment. IEEE Trans. Sustain. Energy 2015, 7, 786-796. [CrossRef]

45. Wu, Q.; Guan, R.; Sun, X.; Wang, Y.; Li, X. SoC balancing strategy for multiple energy storage units with different capacities in islanded microgrids based on droop control. IEEE JEST Power Electron. 2018, 6, 1932-1941. [CrossRef]

46. Shan, Y.; Hu, J.; Guerrero, J.M. A Model Predictive Power Control Method for PV and Energy Storage Systems With Voltage Support Capability. IEEE Trans. Smart Grid 2019, 11, 1018-1029. [CrossRef]

47. Liu, H.; Yang, Y.; Wang, X.; Loh, P.C.; Blaabjerg, F.; Wang, W.; Xu, D.G. An Enhanced Dual Droop Control Scheme for Resilient Active Power Sharing among Paralleled Two-Stage Converters. IEEE Trans. Power Electron. 2016, 32, 1. [CrossRef]

48. Hoang, K.D.; Lee, H.-H. Accurate Power Sharing With Balanced Battery State of Charge in Distributed DC Microgrid. IEEE Trans. Ind. Electron. 2018, 66, 1883-1893. [CrossRef]

49. Ye, Y.; Cheng, K.W.E. Modeling and analysis of series-parallel switched-capacitor voltage equalizer for bat-tery/supercapacitor strings. IEEE J. Emerg. Sel. Top. Power Electron. 2015, 3, 977-983. [CrossRef]

50. Lu, X.; Sun, K.; Guerrero, J.; Vasquez, J.C.; Huang, L. State-of-Charge Balance Using Adaptive Droop Control for Distributed Energy Storage Systems in DC Microgrid Applications. IEEE Trans. Ind. Electron. 2014, 61, 2804-2815. [CrossRef]

51. Locorotondo, E.; Corti, F.; Pugi, L.; Berzi, L.; Reatti, A.; Lutzemberger, G. Design of a Wireless Charging System for Online Battery Spectroscopy. Energies 2021, 14, 218. [CrossRef]

52. Yogarathinam, A.; Chaudhuri, N.R. Stability-Constrained Adaptive Droop for Power Sharing in AC-MTDC Grids. IEEE Trans. Power Syst. 2019, 34, 1955-1965. [CrossRef]

53. Byrne, R.H.; Nguyen, T.; Copp, D.; Chalamala, B.; Gyuk, I. Energy Management and Optimization Methods for Grid Energy Storage Systems. IEEE Access 2018, 6, 13231-13260. [CrossRef]

54. Wang, S.; Geng, G.; Wenlong, L.; Jiang, Q. Impact of Time-Coupled Generator Formulation on Energy Storage Sizing Problem. In Proceedings of the 2018 North American Power Symposium (NAPS), Fargo, ND, USA, 9-11 September 2018; pp. 1-6. [CrossRef]

55. Wang, T.; Nian, H.; Zhu, Z.Q.; Ding, L.; Zhou, B. Flexible Compensation Strategy for Voltage Source Converter Under Unbalanced and Harmonic Condition Based on a Hybrid Virtual Impedance Method. IEEE Trans. Power Electron. 2018, 33, 7656-7673. [CrossRef]

56. Li, S.J.; Li, X.R.; Huang, J.Y.; Yang, X.D.; Ouyang, L.L.; Bi, S.L. Technicaland econimic selection analysis of energy storage power supply for frequency regulation. Acta Energ. Sol. Sinca. 2018, 39, 3550-3557.

57. Vishnoi, R.K.; Joshi, L.P. Challenges in Reliable Power System Planning and Management with Large Scale Infusion of Renewable Sources in India. In Proceedings of the 2019 IEEE PES GTD Grand International Conference and Exposition Asia (GTD Asia), Bangkok, Thailand, 19-23 March 2019; pp. 63-67.

58. Mastrocinque, E.; Ramírez, F.J.; Honrubia-Escribano, A.; Pham, D.T. An AHP-based multi-criteria model for sus-tainable supply chain development in the renewable energy sector. Expert Syst. Appl. 2020, 150, 1-16. [CrossRef]

59. Paul, S.; Nath, A.P.; Rather, Z.H. A Multi-Objective Planning Framework for Coordinated Generation From Offshore Wind Farm and Battery Energy Storage System. IEEE Trans. Sustain. Energy 2019, 11, 2087-2097. [CrossRef]

60. Li, X.D.; Wang, F.; Cao, Y.J.; Wang, L.Y.; Wang, L.Y. Analytic Hierarchy Process Based Quantitative Performance Evaluation of Second-use Battery Energy Storage System. J. Shandong Univ. (Eng. Sci.) 2019, 49, 123-129.

61. Barin, A.; Canha, L.N.; Abaide, A.; Magnago, K.F. Selection of storage energy technologies in a power quality scenario the AHP and the fuzzy logic. In Proceedings of the 2009 35th Annual Conference of IEEE Industrial Electronics, Porto, Portugal, 3-5 November 2009; pp. 3615-3620.

62. Ongaro, F.; Saggini, S.; Mattavelli, P. Li-ion battery-supercapacitor hybrid storage system for a long lifetime photovol-taic-based wireless sensor network. IEEE Trans. Power Syst. 2012, 27, 3944-3952. [CrossRef]

63. Maharjan, L.; Inoue, S.; Akagi, H.; Asakura, J. State-of-Charge (SOC)-Balancing Control of a Battery Energy Storage System Based on a Cascade PWM Converter. IEEE Trans. Power Electron. 2009, 24, 1628-1636. [CrossRef]

64. Gkavanoudis, S.I.; Oureilidis, K.O.; Demoulias, C.S. An adaptive droop control method for balancing the SoC of distributed batteries in AC Microgrids. In Proceedings of the 2016 IEEE 17th Workshop on Control and Modeling for Power Electronics (COMPEL), Trondheim, Norway, 27-30 June 2016; pp. 1-6.

65. Thale, S.; Wandhare, R.; Agarwal, V. A Novel Reconfigurable Microgrid Architecture With Renewable Energy Sources and Storage. IEEE Trans. Ind. Appl. 2015, 51, 1805-1816. [CrossRef]

66. Li, J.L.; Ma, H.M.; Tian, C.G.; Dong, H. Selection of electrochemical energy storage based on interval analytic hierarchy process method. High Volt. Eng. 2016, 42, 2707-2714. 
67. Lu, X.; Sun, K.; Guerrero, J.; Vasquez, J.C.; Huang, L. Double-Quadrant State-of-Charge-Based Droop Control Method for Distributed Energy Storage Systems in Autonomous DC Microgrids. IEEE Trans. Smart Grid 2015, 6, 147-157. [CrossRef]

68. Li, J.H.; Zhang, J.H.; Hu, D.C.; Li, J.L.; Ma, H.M. Comparison and analysis of multi-attribute and multi-objective energy storage system working conditions suitability. Electr. Power Constr. 2018, 39, 2-8.

69. Yang, J.; Yuan, B.; Zhang, F.; Luan, F.; Lu, G.; Xu, Z. Research on the Application Prospect of Energy Storage Technology in Energy Internet. In Proceedings of the 2019 IEEE 3rd International Electrical and Energy Conference (CIEEC), Beijing, China, 7-10 September 2019; pp. 1608-1612.

70. Kim, Y.-S.; Hwang, C.-S.; Kim, E.-S.; Cho, C. State of charge-based active power sharing method in a standalone mi-crogrid with high penetration level of renewable energy sources. Energies 2016, 9, 480. [CrossRef]

71. Liang, J.; Yu, H.; Yang, G.C.; Zhou, Y. Application of Battery Storage Technology in Peak Regulation Optimization of Wind Power System. Electr. Power Inf. Commun. Technol. 2020, 18, 67-73.

72. Wang, S.-J.; Ping, C.; Xue, G.-B. Synergic Optimization of Community Energy Internet Considering the Shared Energy Storage. Electr. Power 2018, 51, 77-84.

73. Yang, J.; Jin, X.; Wu, X.; Acuna, P.; Aguilera, R.P.; Morstyn, T.; Agelidis, V.G. Decentralised control method for dc microgrids with improved current sharing accuracy. IET Gener. Transm. Distrib. 2017, 11, 696-706. [CrossRef]

74. Lei, Q.; Miao, S.H.; Guo, B.F.; Sun, Q.; Ye, C. Comprehensive evaluation of hierarchical storage based on analytic hierarchy process and improved technique for order preference by similarity to ideal solution. Power Syst. Prot. Control. 2017, 45, 13-19.

75. Wang, C.X.; Li, Q.H.; Lei, X.J. Methodology for Analyzing the Value of Energy Storage to Power System Frequency Control of High Shares of Renewable Energy. Electr. Power 2016, 49, 148-152.

76. Yang, J.; Jin, X.; Yang, X.; Wu, X.Z. Overview on power control technologies in hybrid AC-DC microgrid. Power Syst. Technol. 2017, 41, 29-39.

77. Li, J.L.; Ma, H.M.; Hui, D. Present Development Condition and Trends of Energy Storage Technology in the Integration of Distributed Renewable Energy. Trans. China Electrotech. Soc. 2016, 131, 1-20.

78. Morstyn, T.; Hredzak, B.; Agelidis, V.G. Distributed Cooperative Control of Microgrid Storage. IEEE Trans. Power Syst. 2015, 30, 2780-2789. [CrossRef]

79. Kumar, M.B.H.; Saravanan, B. A Solution for Stability Improvement through Compressed Air Energy Storage as Reactive Power Compensating Device under Various Grid Faults. In Proceedings of the 2019 Innovations in Power and Advanced Computing Technologies (i-PACT), Vellore, India, 22-23 March 2019; Volume 1, pp. 1-5.

80. Yang, T.; Han, Z.; Yang, F.; Liang, Y.; Gao, J.; Ji, X. Coordinated Optimal Configuration Method of Hybrid Energy Storage Systems in Energy Internet System. In Proceedings of the 2019 IEEE Innovative Smart Grid Technologies-Asia (ISGT Asia), Chengdu, China, 21-24 May 2019; pp. 1515-1519.

81. Wang, Z.; Liu, Q.; Lu, S.; Chen, X.; Xu, X.; Zhou, X. Distributed Generation Placement Considering Carbon Trading in the Context Of Energy Internet. In Proceedings of the 2020 IEEE 4th Conference on Energy Internet and Energy System Integration (EI2), Wuhan, China, 30 October-1 November 2020; pp. 908-913.

82. Li, Y.; Lu, Y.; Li, H.; Wang, D.; Mu, Z.; Han, X. Adaptability Evaluation of Energy Storage Working Conditions in Different Application Scenarios. In Proceedings of the 2021 4th International Conference on Energy, Electrical and Power Engineering (CEEPE), Chongqing, China, 23-25 April 2021; pp. 103-107. [CrossRef]

83. Zeng, M.; Yang, Y.; Liu, D.; Zeng, B.; Ouyang, S.; Lin, H.; Han, X. Generation-Grid-Load-Storage' Coordinative Optimal Operation Mode of Energy Internet and Key Technologies. Power Syst. Technol. 2016, 40, 114-124.

84. Nikolakakis, T.; Fthenakis, V.M.; Nokolakakis, T. Compressed Air Energy Storage Models for Energy Arbitrage and Ancillary Services: Comparison Using Mixed Integer Programming Optimization with Market Data from the Irish Power System. Energy Technol. 2018, 6, 1290-1301. [CrossRef]

85. Zhu, Y.Q.; Hao, J.C.; Zhao, N.; Wang, X. Demands functions and action manners of energy storage in Energy Internet. Adv. Technol. Electr. Eng. Energy 2018, 37, 68-75.

86. Zhu, Y.; Zhao, N.; Wang, F.; Wang, X. Energy storage coordination among various energy networks in energy Internet. Adv. Technol. Electr. Eng. Energy 2018, 37, 10-16.

87. Nazar, A.; Anwer, N. Accommodative Energy Market for Battery Energy Storage and Grid Balancing. In Proceedings of the 2020 International Conference on Emerging Frontiers in Electrical and Electronic Technologies (ICEFEET), Patna, India, 10-11 July 2020; pp. 1-5.

88. Silva-Saravia, H.; Pulgar-Painemal, H.; Mauricio, J.M. Flywheel energy storage model control and location for improving stability: The chilean case. IEEE Trans. Power Syst. 2017, 32, 3111-3119. [CrossRef]

89. Banshwar, A.; Sharma, N.K.; Sood, Y.R.; Shrivastava, R. Renewable energy sources as a new participant in ancillary service markets. Energy Strat. Rev. 2017, 18, 106-120. [CrossRef]

90. Luo, X.; Wang, J.; Dooner, M.; Clarke, J. Overview of current development in electrical energy storage technologies and the application potential in power system operation. Appl. Energy 2015, 137, 511-536. [CrossRef]

91. Koliou, E.; Eid, C.; Chaves-Ávila, J.P.; Hakvoort, R.A. Demand response in liberalized electricity markets: Analysis of aggregated load participation in the German balancing mechanism. Energy 2014, 71, 245-254. [CrossRef]

92. Sidhu, A.S.; Pollitt, M.G.; Anaya, K.L. A social cost benefit analysis of grid-scale electrical energy storage projects: A case study. Appl. Energy 2018, 212, 881-894. [CrossRef] 
93. Hannan, M.; Hoque, M.; Mohamed, A.; Ayob, A. Review of energy storage systems for electric vehicle applications: Issues and challenges. Renew. Sustain. Energy Rev. 2017, 69, 771-789. [CrossRef]

94. Mahapatra, U. Energy Storages and Technologies for Electric Vehicle. In Proceedings of the 2021 Innovations in Energy Management and Renewable Resources(52042), Kolkata, India, 5-7 February 2021; pp. 1-3.

95. Kouchachvili, L.; Yaici, W.; Entchev, E. Hybrid battery/supercapacitor energy storage system for the electric vehicles. J. Power Sources 2018, 374, 237-248. [CrossRef]

96. Lucas, A.; Chondrogiannis, S. Smart grid energy storage controller for frequency regulation and peak shaving, using a vanadium redox flow battery. Int. J. Electr. Power Energy Syst. 2016, 80, 26-36. [CrossRef]

97. Song, Z.; Li, J.; Hou, J.; Hofmann, H.; Ouyang, M.; Du, J. The battery-supercapacitor hybrid energy storage system in electric vehicle applications: A case study. Energy 2018, 154, 433-441. [CrossRef]

98. Davies, D.M.; Verde, M.G.; Mnyshenko, O.; Chen, Y.R.; Rajeev, R.; Meng, Y.S.; Elliott, G. Combined economic and technological evaluation of battery energy storage for grid applications. Nat. Energy 2019, 4, 42-50. [CrossRef]

99. Zacharia, L.; Tziovani, L.; Savva, M.; Hadjidemetriou, L.; Kyriakides, E.; Bintoudi, A.; Tsolakis, A.; Tzovaras, D.; Martinez-Ramos, J.L.; Marano, A.; et al. Optimal Energy Management and Scheduling of a Microgrid in Grid-Connected and Islanded Modes. In Proceedings of the 2019 International Conference on Smart Energy Systems and Technologies (SEST), Porto, Portugal, 9-11 September 2019; pp. 1-6.

100. Ramakrishnan, J.; Hashemi, S.; Traholt, C. Assessment of Energy Storage Systems for Multiple Grid Service Provision. In Proceedings of the 2020 IEEE 14th International Conference on Compatibility, Power Electronics and Power Engineering (CPE-POWERENG), Setubal, Portugal, 8-10 July 2020; Volume 1, pp. 333-339.

101. Parhizi, S.; Khodaei, A.; Shahidehpour, M. Market-Based Versus Price-Based Microgrid Optimal Scheduling. IEEE Trans. Smart Grid 2018, 9, 615-623. [CrossRef]

102. Borne, O.; Korte, K.; Perez, Y.; Petit, M.; Purkus, A. Barriers to entry in frequency-regulation services markets: Review of the status quo and options for improvements. Renew. Sustain. Energy Rev. 2018, 81, 605-614. [CrossRef]

103. Hou, Y.; Wang, Z.; Li, H. Design of Smart Energy Converter with Distribution and Storage Integrated for LVDC Distribution Grid. In Proceedings of the 2020 5th International Conference on Power and Renewable Energy (ICPRE), Shanghai, China, 12-14 September 2020; pp. 528-532. 